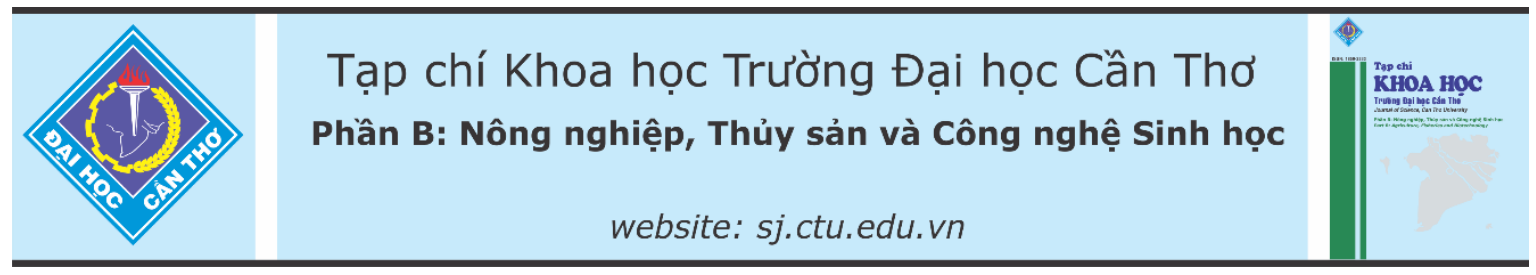

DOI:10.22144/ctu.jvn.2021.150

\title{
HIỆN TRẠNG SỬ DỤNG, LƯU TỒN VÀ THỬ NGHIỆM XỦ LÝ PACLOBUTRAZOL TRONG ĐẤT LÚA TẠI HUYỆN CHÂU PHÚ, TỈNH ẤN GIANG
}

\author{
Nguyễn Hửu Thiện ${ }^{1}$, Đỗ Bá Tân ${ }^{2}$, Nguyễn Văn Thảo ${ }^{3}$ và Nguyễn Khởi Nghĩa ${ }^{1 *}$ \\ ${ }^{1}$ Bộ môn Khoa họ đất, Khoa Nông nghiệp, Truờng Đại học Cần Tho \\ ${ }^{2}$ Trung tâm Nghiên cứu Phát triển, Công ty cổ phần Phân bón Dầu khí Cà Mau \\ ${ }^{3}$ Hợp tác xã Nông nghiệp Thuận Thới, xã Thuận Thới, huyện Trà Ôn, tỉnh Vĩnh Long \\ *Nguoòi chịu trách nhiệm về bài viết: Nguyễn Khởi Nghĩa (email: nknghia@ctu.edu.vn)
}

\section{Thông tin chung:}

Ngày nhận bài: 14/04/2021

Ngày nhận bài sủa: 19/05/2021

Ngày duyệt đăng: 29/10/2021

Title:

Current status of

Paclobutrazol use, its residues and remediation approach to decontaminating rice soil in Chau Phu district, An Giang province

\section{Tù khóa:}

Chế phẩm vi khuẩn, lúa nếp, lưu tồn, phân hủy,

paclobutrazol

\section{Keywords:}

Bacterial product, decomposition, $\mathrm{PBZ}$, residue, sticky rice

\section{ABSTRACT}

The objective of this study was to investigate the current status of paclobutrazol (PBZ) use in rice cultivation, to evaluate the residues of $P B Z$ in soils, and to examine the $P B Z$ biodegradation efficiency of a bacterial product in rice soil in Chau Phu district, An Giang province. In total 32 rice farmers were interviewed. Then, 10 soil samples from 10 fields using PBZ were collected and analyzed for PBZ residues and an experiment was conducted in the field to examine the PBZ biodegradation efficiency of bacterial product in soil in a completely randomized block design with 4 treatments and 4 replicates. The results showed that 100\% of the surveyed farmers have ever used PBZ in their rice cultivation to control the height and collapse of rice plants. The two most popular commercial products containing PBZ were Bidamin 15WP and Bonsai 10 WP There are two well-known commercial products containing PBT which are Bidamin 15WP and Bonsai $10 \mathrm{WP}$ with dosage used being higher than the recommended one for a long period of time. PBZ residues in 10 soil samples were ranged from $0.09 \mathrm{mg} / \mathrm{kg}$ to $1.11 \mathrm{mg} / \mathrm{kg}$ soil. In addition, the treatment used with $P B Z$ degrading bacterial product completely degraded PBZ in the soil after 35 experimental days after sowing, however, it did not help to increase the yield of sticky rice as compared to the treatment without use of bacterial product after 1 experimental crop. Thus, PBZ degrading bacterial product has an efficiency in PBZ degradation in rice soil.

\section{TÓM TẮT}

Đề tài được thực hiện với muc tiêu khảo sát tình hình sủ dụng hoạt chất paclobutrazol (PBZ) trong canh tác lúa, đánh giá sư luu tồn PBZ trong đất lúa và khả năng phân hủy hoạt chất $P B Z$ của chế phẩm vi khuẩn trong đất tại huyện Châu Phú, tỉnh An Giang. Tổng công 32 họ nông dân trồng lúa được phỏng vấn. Sau đó, 10 mẫu đất tù̀ 10 ruộng có sử dụng $P B Z$ được thu, phân tích luu tồn $P B Z$ và thí nghiệm phân hủy hoạt chất PBZ trong đất của chế phầm vi khuẩn được bố tri theo thể thức khối hoàn toàn ngẫu nhiên gồm 4 nghiệm thức và 4 lần lặp lại. Kết quả cho thấy $100 \%$ nông dân khảo sát sử dụng hoạt chất $P B Z$ cho lúa nhằm giảm đổ ngã. Hai sản phẩm thuoơng mại được sử dụng phổ biến nhất là Bidamin $15 \mathrm{WP}$ và Bonsai 10 WP với lượng cao hơn nhiều làn so với khuyến cáo. Hàm lượng PBZ luu tồn trong 10 mẫu đất dao động tù 0,09 đến $1,11 \mathrm{mg} / \mathrm{kg}$ đất. Bên cạnh đó, nghiệm thức sủ dụng chế phẩm vi khuẩn giúp hủy hoàn toàn lượng PBZ luu tồn trong đất sau 35 ngày thí nghiệm, tuy nhiên không giúp gia tăng năng suất nếp so với nghiệm thức không sử dụng chế phẩm vi khuấn sau 1 vu thí nghiệm. Nhu vậy, chế phẩm vi khuẩn phân hủy PBZ có hiệu quả phân hủy hoạt chất PBZ trong đất lúa. 


\section{1. ĐẶT VẤN ĐỀ}

Trong quá trình sản xuất lúa nói chung và lúa nếp nói riêng, việc cây lúa nếp đổ ngã gây thất thoát đến năng suất và làm giảm chất lượng hạt vì khi cây bị đỗ ngã quá trình tạo hạt lúa bị đình trệ do sự vận chuyển vật chất vào trong hạt bị cản trở (Yoshida, 1981). Việc đỗ ngã còn gây khó khăn trong lúc thu hoạch và làm tăng giá thành sản xuất do giá nhân công thu hoạch cho cây lúa bị đỗ ngã cao hơn.

Paclobutrazol (PBZ) là một hợp chất hóa học hữu cơ làm ức chế sự phát triển thực vật và là chất đối kháng với hormone thực vật gibberellin, hoạt động bằng cách ức chế sinh tổng hợp gibberellin, làm giảm sự phát triển của các kẽ lá để tạo ra các thân cành, tăng sự phát triển của rễ, ra quả sớm và tăng số hạt ở các loại cây trồng như cà chua và hồ tiêu. Trên cây ăn trái, PBZ là hợp chất dùng để xử lý ra hoa hiệu quả (Trần Văn Hâu và ctv., 2001). Bên cạnh đó, trên nhóm cây lúa và nếp, nghiên cứu cho thấy $\mathrm{PBZ}$ còn giúp hạn chế chiều cao cây, từ đó giúp giảm sự đỗ ngã trên nhiều giống lúa gạo và lúa nếp khi nông dân có thói quen sử dụng lượng phân đạm cao quá mức khuyến cáo (Ueno et al., 1987). Hiện nay, nông dân trồng lúa và nếp trên địa bàn huyện Châu Phú và Phú Tân, tỉnh An Giang nói riêng và nông dân canh tác lúa nếp ở khu vực Đồng bằng sông Cửu Long nói chung đang sử dụng PBZ để hạn chế đổ ngã và bảo đảm năng suất trong quá trình canh tác. Tuy nhiên, các thông tin về nông dân sử dụng $\mathrm{PBZ}$ với liều lượng cao cho cây lúa và lúa nếp cho khu vực này như thế nào vẫn còn chưa rõ. Ngoài ra, mức độ lưu tồn PBZ trong đất trồng lúa nếp tại huyện Châu Phú, tỉnh An Giang như thế nào vần chưa được nghiên cứu.

Do PBZ là hợp chất hóa học hữu cơ thuộc nhóm triazole, khó phân hủy bởi vi sinh vật trong đất. Bên cạnh đó, $\mathrm{PBZ}$ rất độc cho sức khỏe của con người và ảnh hưởng nghiêm trọng đến môi trường sinh thái (Watson \& Jacobs, 2012). Do đó, cần có biện pháp để xử lý ô nhiễm PBZ trong đất nông nghiệp. Trong số các biện pháp xử lý được ứng dụng, biện pháp xử lý bằng công nghệ vi sinh được quan tâm và khuyến khích sử dụng ở Việt Nam và thế giới do thân thiện với môi trường sinh thái (Đặng Phạm Thu Thảo, 2014). Chế phẩm vi khuẩn dạng lỏng chứa ba dòng vi khuẩn phân hủy hiệu quả PBZ như CT3- $9_{2}$ được phân lập từ đất trồng cây ăn trái bị nhiễm $\mathrm{PBZ}$ bởi Đặng Phạm Thu Thảo (2014), hai dòng vi khuẩn B61 và $\mathrm{B} 2-\mathrm{O}$ được phân lập từ lá cây bắp bởi Dương
Trúc Mai (2019). Tuy nhiên, việc đánh giá hiệu quả phân hủy $\mathrm{PBZ}$ trong đất của 3 dòng vi khuẩn này chỉ mới thực hiện bước đầu trong phòng thí nghiệm và chưa được nghiên cứu và khảo sát ở điều kiện thực tế ngoài đồng ruộng. Do đó, nghiên cứu này được thực hiện nhằm mục tiêu khảo sát tình hình sử dụng hoạt chất PBZ trong nông dân, khảo sát mức độ lưu tồn $\mathrm{PBZ}$ trong đất trồng lúa nếp và đánh giá hiệu quả của chế phẩm vi sinh chứa ba dòng vi khuẩn phân hủy PBZ trong đất trồng lúa nếp tại huyện Châu Phú, tỉnh An Giang.

\section{PHƯƠNG TIÊ̂N VÀ PHƯƠNG PHÁP NGHIÊN CÚU}

\subsection{Vật liệu thí nghiệm}

\subsubsection{Nguồn vi khuẩn}

Ba dòng vi khuẩn có khả năng phân hủy hoạt chất $\mathrm{PBZ}$ được sử dụng để làm chế phẩm vi sinh sử dụng trong nghiên cứu này gồm dòng vi khuẩn CT3$9_{2}$ được phân lập từ đất vườn xoài ở huyện Phong Điền, thành phố Cần Thơ có khả năng phân hủy $47,5 \% \mathrm{PBZ}$ trong đất trồng xoài ở điều kiện phòng thí nghiệm sau 15 ngày nuôi cấy (Đặng Phạm Thu Thảo, 2014). Hai dòng vi khuẩn có ký hiệu B6-1 và $\mathrm{B} 2-\mathrm{O}$ được phân lập từ lá bắp có khả năng phân hủy tốt $\mathrm{PBZ}$ với lần lượt là $25,4 \%$ và $14,5 \%$ sau 30 ngày nuôi cấy trong môi trường MSM lỏng (Dương Trúc Mai, 2019). Chế phẩm vi khuẩn phân hủy hoạt chất PBZ có chứa 3 dòng vi khuẩn CT3-9, $\mathrm{B} 6-1$ và $\mathrm{B} 2-$ $\mathrm{O}$ được nhân nguồn và chuẩn bị thành dạng lỏng (mật số khoảng $10^{8} \mathrm{CFU} / \mathrm{mL}$ chế phẩm) để phục vụ cho thí nghiệm được thực hiện tại Phòng thí nghiệm Vi sinh vật Đất, Bộ môn Khoa học Đất, Khoa Nông nghiệp, Trường Đại học Cần Thơ.

\subsubsection{Giống lúa nếp}

Giống lúa nếp CK92 (Nếp Đùm Phú Tân) có thời gian sinh trưởng 100-105 ngày, cao cây 106$112 \mathrm{~cm}$, bông dài $2,5-23 \mathrm{~cm}$, trọng lượng 1.000 hạt 22-25 $\mathrm{g}$ được mua của Công ty Cổ phần Tập đoàn Lộc Trời tại huyện Châu Phú, tỉnh An Giang (Võ Công Thành, 2011).

\subsubsection{Chuẩn bị phiếu điều tra}

Phiếu điều tra được thiết kế trước khi đi điều tra nông hộ trồng lúa nếp với các thông tin cần thu thập gồm thông tin cá nhân của nông dân, lịch sử sử dụng các sản phẩm thương mại chứa hoạt chất $\mathrm{PBZ}$, tần suất sử dụng trong một vụ, thời gian, liều lượng, sự hiểu biết của nông dân về hoạt chất này. 


\subsection{Phương pháp nghiên cứu}

2.2.1. Đánh giá mức độ luu tồn PBZ trong đất trồng lúa nếp tại huyện Châu Phú, tỉnh An Giang

a. Điều tra, thu thập thông tin về kỹ thuật canh tác và tình hình sư dụng $P B Z$ trên lúa nếp

Việc điều tra và phỏng vấn nông hộ được tiến hành tại hai xã Bình Mỹ và Bình Chánh, huyện Châu Phú, tỉnh An Giang dựa trên các thông tin trong phiếu đều tra đã được thiết kế. Các hộ nông dân được điều tra phải thoả mãn các điều kiện như (1) có diện tích đất trồng lúa nếp ít nhất $3.000 \mathrm{~m}^{2}$ và (2) có thời gian canh tác lúa nếp trên 5 năm. Việc phỏng vấn nông dân trồng lúa nếp dựa trên bảng câu hỏi điều tra gồm các thông tin chủ yếu được thu thập như: diện tích canh tác, kinh nghiệm canh tác, tên thương mại chứa hoạt chất PBZ, liều lượng sử dụng hoạt chất $\mathrm{PBZ}$, thời điểm sử dụng, số lần sử dụng trên mỗi vụ, cách sử dụng, thời gian sử dụng, biểu hiện của cây lúa nếp khi bị bón $\mathrm{PBZ}$ quá liều, ảnh hưởng của $\mathrm{PBZ}$ đối với môi trường, nhận thức của nông dân về tính độc của $\mathrm{PBZ}$ đối với sức khỏe con người và môi trường sinh thái.

\section{b. Thu thập mẫu đất và phân tích hàm luợng} PBZ luu tồn trong 10 mẫu đất trồng lúa nếp

Dựa vào kết quả điều tra nông dân về tình hình sử dụng $\mathrm{PBZ}$ trên lúa nếp, 10 hộ nông dân có sử dụng $\mathrm{PBZ}$ với liều lượng cao và thường xuyên trong 1 vụ tại khu vực điều tra được chọn ra để tiến hành thu mẫu đất và phân tích hàm lượng $\mathrm{PBZ}$ lưu tồn trong đất trồng lúa nếp. Việc thu mẫu đất ruộng trồng lúa nếp tại mỗi hộ nông dân được thực hiện bằng cách thu đất ở nhiều vị trí khác nhau theo hình zig zag trên bề mặt ruộng ở độ sâu 0-20 cm, sau đó trộn lại thành 1 mẫu để phân tích hàm lượng PBZ lưu tồn trong đất. Hàm lượng $\mathrm{PBZ}$ trong đất được xác định theo phương pháp của Liu et al. (2015). Cách thực hiện như sau: cân $3 \mathrm{~g}$ đất khô kiệt vào lọ pi $12 \mathrm{~mL}$, sau đó cho vào lần lượt $5 \mathrm{~mL}, 4 \mathrm{~mL}$ và 3 $\mathrm{mL}$ hỗn hợp dung môi hữu cơ gồm Toluen:Acetone với tỉ lệ $2: 1(\mathrm{v} / \mathrm{v})$ cho mỗi lần trích. Các mẫu được lắc trên máy lắc ngang tốc độ 150 vòng/phút trong 24 giờ cho các lần trích mẫu. Dịch trích bên trên (dung môi) được thu sau khi ly tâm mẫu trên máy ly tâm với tốc độ 4.000 vòng/phút trong 3 phút, kế đến mẫu được để bay hơi tự nhiên xuống thể tích còn khoảng $1 \mathrm{~mL}$ trong tủ hút. Dịch trích chứa $\mathrm{PBZ}$ sau khi trích được lọc qua cột sắc ký Alumina để loại bỏ tạp chất. Trước tiên, quy trình bất hoạt Alumina được thực hiện bằng cách nung Alumina trong lò nung ở nhiệt độ $550^{\circ} \mathrm{C}$ trong 24 giờ, sau đó bất hoạt Alumina bằng nước khử khoáng với lượng nước cho vào bằng $3 \%$ trọng lượng của Alumina. Cột lọc thủy tinh tuần tự gồm các thành phần như $1 \mathrm{~cm}$ gòn thủy tinh và $1 \mathrm{~g}$ Alumina; sau đó, cho vào cột thủy tinh 1 $\mathrm{cm} \mathrm{Na} \mathrm{SO}_{4}$. Cột được rửa bằng $1,3 \mathrm{~mL}$ hỗn hợp dung môi hữu cơ dicloromethane:hexane tỉ lệ $2: 1$ $(\mathrm{v} / \mathrm{v})$ và $4 \mathrm{~mL}$ hexanes. Cuối cùng, dịch trích chứa PBZ được cho vào cột lọc đã xử lý. Phần dịch trích được thu sau khi chạy qua cột lọc và tiến hành cô cạn mẫu lọc xuống thể tích $1 \mathrm{~mL}$ bằng cách cho bay hơi tự nhiên trong tủ hút trước khi phân tích trên máy sắc ký lỏng hiệu năng cao HPLC (High Performance Liqid Chromatography) với các thông số: cột $\mathrm{C} 18$ (dài $25 \mathrm{~cm}$, đường kính trong: 4,6 mm), tî lệ pha động acetone nitrile: nước khử khoáng 50:50 với bước sóng $225 \mathrm{~nm}$. Thời gian xuất hiện peak của $\mathrm{PBZ}$ vào phút 12 .

\subsection{2. Đánh giá hiệu quả phân hủy hoạt chất PBZ luu tồn trong đất trồng lúa nếp của chế phẩm vi khuẩn phân hủy PBZ tại huyện Châu Phú, tỉnh An Giang}

\section{a. Bố trí thí nghiệm}

Thí nghiệm ngoài đồng được bố trí tại ấp Bình Thành, xã Bình Mỹ, huyện Châu Phú, tỉnh An Giang trên nền đất có hàm lượng $\mathrm{PBZ}$ lưu tồn trong đất cao nhất trong tổng số 10 mẫu đất được lựa chọn và phân tích hàm lượng $\mathrm{PBZ}$ lưu tồn trong đất ở hai xã Bình Mỹ và Bình Chánh, huyện Châu Phú, tỉnh An Giang. Khu thí nghiệm có tổng diện tích là $480 \mathrm{~m}^{2}$ và được chia thành 16 lô có diện tích bằng nhau $(5 \mathrm{~m} \times 6 \mathrm{~m}$ $=30 \mathrm{~m}^{2}$ ). Các lô đất thí nghiệm được cách ly với nhau bằng các bờ xung quanh. Bên trong lô được cày xới và làm phẳng mặt ruộng trước khi sạ hạt giống. Mẫu đất đầu vụ được thu để phân tích một số đặc tính lý hóa và sinh học đất vào thời điểm trước khi phân các lô thí nghiệm bằng cách thu ở nhiều vị trí khác nhau trên mặt ruộng khu thí nghiệm ở độ sâu 0-20 cm. Đặc tính đất đầu vụ được phân tích tại phòng thí nghiệm Hóa lý và Sinh học đất thuộc Bộ môn Khoa học Đất, Khoa Nông nghiệp, Trường Đại học Cần Thơ. Một số đặc tính lý, hóa và sinh học đất đầu vụ được trình bày trong Bảng 1 . 
Bảng 1. Đặc tính lý, hóa và sinh học đất đầu tại xã Bình Mỹ, huyện Châu Phú, tỉnh An Giang (8/2020)

\begin{tabular}{lr|lr}
\hline Đặc tính đất & Kết quả & Đặc tính đất & Kết quả \\
\hline $\mathrm{pH}_{\mathrm{H} 2 \mathrm{O}}$ & 5,28 & Mật số vi khuẩn, $(\mathrm{CFU} / \mathrm{g})$ & $1,04 \times 10^{6}$ \\
$\mathrm{EC}$ bão hòa, $(\mathrm{mS} / \mathrm{cm})$ & 0,12 & Mật số nấm, $(\mathrm{CFU} / \mathrm{g})$ & 0 \\
$\mathrm{Chất} \mathrm{hữu} \mathrm{cơ,}(\%)$ & 4,40 & Mật số xạ khuẩn, $(\mathrm{CFU} / \mathrm{g})$ & $3,38 \times 10^{4}$ \\
$\mathrm{~N}_{\mathrm{ts}},(\% \mathrm{~N})$ & 0,20 & Dung trọng, $\left(\mathrm{g} / \mathrm{cm}^{3}\right)$ & 1,07 \\
$\mathrm{NH}_{4}{ }^{+}-\mathrm{N},(\mathrm{mg} / \mathrm{kg})$ & 9,90 & Độ xốp, $(\%)$ & 56,01 \\
$\mathrm{NO}_{3}-\mathrm{N},(\mathrm{mg} / \mathrm{kg})$ & 0,17 & Thành phần cơ giới & Sét \\
$\mathrm{P}_{\mathrm{ts}},\left(\% \mathrm{P}_{2} \mathrm{O}_{5}\right)$ & 0,06 & $\%$ cát & 0,26 \\
$\mathrm{P}$ dễ tiêu, $(\mathrm{mg} / \mathrm{kg})$ & 7,98 & $\%$ thịt & 27,84 \\
$\mathrm{~K}$ tồng, $\left(\% \mathrm{~K}_{2} \mathrm{O}\right)$ & 2,04 & $\%$ sét & 71,90 \\
$\mathrm{~K}$ trao đổi, $(\mathrm{meq} / 100 \mathrm{~g})$ & 0,17 & PBZ lưu tồn, $(\mathrm{mg} / \mathrm{kg})$ & 1,11 \\
\hline
\end{tabular}

Thí nghiệm được bố trí vào vụ Thu Đông 2020 (8-12/2020) theo thể thức khối hoàn toàn ngẫu nhiên gồm 4 nghiệm thức và 4 lần lặp lại, mỗi lô thí nghiệm tương ứng với 1 lặp lại. Các nghiệm thức được liệt kê như sau:

Nghiệm thức 1: Đối chứng (bón phân NPK theo nông dân).

Nghiệm thức 2: NPK + phân hữu cơ (2 tấn/ha).

Nghiệm thức 3: NPK + chế phẩm vi sinh $(5$ lít/1000 $\mathrm{m}^{2}$ ).

Nghiệm thức 4: NPK + phân hữu cơ (2 tấn/ha) + chế phẩm vi sinh (5 lít/1000 $\left.\mathrm{m}^{2}\right)$.

Phân hữu cơ được sử dụng trong thí nghiệm là phân RealStrong Acti-Plus có thành phần gồm $50 \%$ chất hữu cơ, $2 \%$ axit humic, tỷ lệ $\mathrm{C} / \mathrm{N}=12$ của Công ty Phân bón và Hóa chất dầu khí (PVFCCo) được nông dân canh tác lúa nếp ở huyện Châu Phú sử dụng phổ biến và được bón 1 lần vào thời điểm chuẩn bị đất. Mật độ gieo sạ với mức $40 \mathrm{~kg} / \mathrm{ha}$ và thực hiện công việc cấy tỉa và trồng dặm ở thời điểm 15 ngày sau khi sạ (NSS). Phân NPK được sử dụng trong thí nghiệm gồm phân urea $(46 \% \mathrm{~N})$ được sản xuất bởi Công ty Cổ phần Phân bón dầu khí Cà Mau, Kali Phú Mỹ $\left(61 \% \mathrm{~K}_{2} \mathrm{O}\right)$ và DAP Phú Mỹ $(18 \% \mathrm{~N}$, $\left.46 \% \mathrm{P}_{2} \mathrm{O}_{5}\right)$ với công thức bón phân $162 \mathrm{~N}-37 \mathrm{P}_{2} \mathrm{O}_{5-}$ $73 \mathrm{~K}_{2} \mathrm{O} \mathrm{kg} / \mathrm{ha}$ (công thức phân được tính dựa trên lượng phân bón hóa học nông dân sử dụng) và được chia làm 3 lần bón cư thể như sau: ở thời điểm 15 ngày sau sạ (NSS) thực hiện bón $20 \mathrm{~kg}$ Urea/1000 $\mathrm{m}^{2}, 8 \mathrm{~kg} \mathrm{KCl} / 1000 \mathrm{~m}^{2}$; thời điểm $25 \mathrm{NSS}$ bón $6 \mathrm{~kg}$ UREA $/ 1000 \mathrm{~m}^{2}$ và $8 \mathrm{~kg} \mathrm{DAP} / 1000 \mathrm{~m}^{2}$; đến thời điểm $45 \mathrm{NSS}$ bón $6 \mathrm{~kg}$ Urea/1000 $\mathrm{m}^{2}$ và $4 \mathrm{~kg}$ $\mathrm{KCl} / 1000 \mathrm{~m}^{2}$. Sản phẩm thương mại chưa hoạt chất PBZ bón cho cây lúa nếp phổ biến ở khu vực thí nghiệm là Bidamin 15WP (chứa $15 \%$ hoạt chất PBZ) của Công ty Đồng Xanh được bón với liều lượng $600 \mathrm{~g} / 1000 \mathrm{~m}^{2}$ vào thời điểm $25 \mathrm{NSS}$ bằng cách trộn chung với phân hóa học. Nước của từng ô thí nghiệm được quản lý theo phương pháp của nông dân bằng cách duy trì mực nước trên mặt ruộng ở mức $5-10 \mathrm{~cm}$, sau đó khi nước rút đến thời điểm mặt ruộng vừa khô, cấp nước ngập mặt ruộng trở lại, lặp lại quy trình đến giai đoạn thu hoạch. Chế phẩm vi khuẩn chứa 3 dòng vi khuẩn phân hủy hoạt chất $\mathrm{PBZ}$ có ký hiệu CT3-92, B6-1 và B2-O) có khả năng phân hủy $\mathrm{PBZ}$ được phun vào đất trước khi gieo hạt với liều lượng 5 lít/1000 $\mathrm{m}^{2}$. Cỏ dại được quản lý bằng phương pháp thủ công, riêng sâu bệnh hại trên lúa được quản lý bằng biện pháp IPM và hạn chế tối đa việc sử dụng thuốc bảo vệ thực vật hóa học.

\section{b. Các chỉ tiêu theo dõi}

(1) Chiều cao cây: Chọn ngẫu nhiên 5 cây trong khung $0,25 \mathrm{~m}^{2}$, đo từ mặt đất đến chóp lá cao nhất ở thời điểm 30 và 60 NSS (khi cây nếp chưa trổ bông) và đến chóp bông ở thời điểm thu hoạch.

(2) Số chồi: Đếm tất cả các chồi trong khung sắt cố định có diện tích $0,25 \mathrm{~m}^{2}$ sau đó quy đổi sang 1 $\mathrm{m}^{2}$.

(3) Số bông $/ \mathrm{m}^{2}$ : Đếm tất cả số bông trong khung $0,25 \mathrm{~m}^{2}$ cố định và sau đó quy đổi thành số bông $/ \mathrm{m}^{2}$.

(4) Chiều dài bông $(\mathrm{cm})$ : Chọn ngẫu nhiên 5 bông trong khung $0,25 \mathrm{~m}^{2}$ cố định để đo từ cổ bông đến chóp đuôi hạt cuối cùng ở thời điểm thu hoạch.

(5) Số hạt/bông, tỷ lệ hạt chắc/bông, khối luợng 1.000 hạt và năng suất lý thuyết: Đếm số hạt chắc và lép của 5 bông ngẫu nhiên trong khung $0,25 \mathrm{~m}^{2}$ cố định để xác định số hạt/bông và tính tỷ lệ hạt chắc/bông. Năng suất lý thuyết được tính theo công thức sau: $\mathrm{W}_{\mathrm{lt}}=\mathrm{A} \times \mathrm{B} \times \mathrm{W}_{1000 \text { hạt, trong đó (A là số }}$ bông $/ \mathrm{m}^{2}$; $\mathrm{B}$ là số hạt chắc/bông), sau đó quy đổi thành năng suất lý thuyết (tấn/ha).

(6) Sinh khối khô (tấn/ha): Cắt sát gốc tất cả các bụi lúa trong ô $5 \mathrm{~m}^{2}$, cân tất cả khối lượng rơm sau khi đã thu hết hạt và lấy một lượng xác định về phòng thí nghiệm để xác định ẩm độ ở thời điểm thu hoạch và quy về khối lượng khô kiệt. 
(7) Năng suất thực tế: Thu tổng khối lượng hạt/5 $\mathrm{m}^{2}$ và xác định ẩm độ hạt lúa tươi, sau đó quy đổi năng suất lúa nếp (tấn/ha). Năng suất lúa nếp được tính theo công thức sau: $\mathrm{W}_{\mathrm{a}}=\left[\mathrm{W}_{\mathrm{b}} \mathrm{x} 10.000\left(\mathrm{~m}^{2}\right) \mathrm{x}\right.$ $\left.\left(100-\mathrm{H}_{\mathrm{b}}\right)\right] /\left[1000 \times 5\left(\mathrm{~m}^{2}\right) \times\left(100-\mathrm{H}_{\mathrm{a}}\right)\right]$, trong đó: $\mathrm{W}_{\mathrm{a}}$ là năng suất thực tế ở ẩm độ $\mathrm{H}_{\mathrm{a}}\left(\right.$ tấn.ha $\left.\mathrm{a}^{-1}\right), \mathrm{H}_{\mathrm{a}}$ là ẩm độ chuẩn $14 \%, \mathrm{~W}_{\mathrm{b}}$ : khối lượng lúa tươi thu từ $5 \mathrm{~m}^{2}$ $(\mathrm{kg}), \mathrm{H}_{\mathrm{b}}$ là ẩm độ của hạt lúa tươi.

(8) Hàm lương PBZ luu tồn trong đất: Tham khảo mục 2.4.1b cho phương pháp phân tích lưu tổn PBZ trong đất.

\subsection{Xử lý số liệu}

Số liệu thí nghiệm được xử lý trên phần mềm Excel và kiểm định thống kê $\mathrm{ANOVA}$, so sánh bằng phép thử Tukey bằng phần mềm Minitab 16.2.

\section{KẾT QUẢ VÀ THẢO LUẬN}

\section{1. Điều tra về kỹ thuật canh tác lúa nếp và tình hình sử dụng $\mathrm{PBZ}$ trên lúa nếp tại huyện Châu Phú, tỉnh An Giang}

Bình Mỹ và Bình Chánh là 2 trong 12 xã của huyện Châu Phú, tỉnh An Giang có thế mạnh về sản xuất nông nghiệp do có diện tích đất canh tác nông nghiệp lớn và đặc tính đất phù sa có độ phì nhiêu cao. Tổng cộng có 32 hộ nông dân trồng lúa nếp được điều tra tại hai xã do thỏa mãn các điều kiện về hộ được điều tra. Trong đó, 22 hộ nông dân ở xã Bình Mỹ, chiếm $68,75 \%$ tổng số hộ khảo sát và xã Bình Chánh là 11 hộ, chiếm 31,25\%. Các nông hộ được điều tra ở khu vực này chủ yếu chuyên canh lúa hoặc lúa nếp (3 vụ/năm) với các giống lúa chủ lực như OM5451, OM4218, Đài Thơm 8, CK92 và giống nếp đùm CK203 với kinh nghiệm canh tác từ 5 năm trở lên.

Kết quả khảo sát tình hình sử dụng hoạt chất PBZ của các nông hộ ở hai xã được trình bày trong Bảng 2 cho thấy đa số các hộ nông dân được điều tra sử dụng các sản phẩm thương mại chứa hoạt chất PBZ chủ yếu trên cây lúa nếp để ức chế sinh trưởng về chiều cao cây nhằm chống đỗ ngã, trong khi việc sử dụng các sản phẩm $\mathrm{PBZ}$ cho cây lúa thì không phổ biến khi có $78,1 \%$ số hộ điều tra canh tác nếp và chỉ có $21,9 \%$ canh tác lúa ở thời điểm khảo sát.

Kết quả điều tra trong tổng số 32 hộ khảo sát cho thấy $100 \%$ hộ nông dân được khảo sát ở hai xã Bình Mỹ và Bình Chánh thuộc huyện Châu Phú, tỉnh An Giang đều sử dụng các sản phẩm chứa hoạt chất PBZ thuộc dạng bột, rất khó tan hoặc không tan trong nước. Vì vậy, nông dân đã sử dụng các sản phẩm chứa hoạt chất $\mathrm{PBZ}$ bằng cách trộn với phân hóa học và bón đều trên mặt ruộng canh tác lúa và lúa nếp theo các giai đoạn bón phân với các sản phẩm thương mại chứa hoạt chất $\mathrm{PBZ}$ được nông dân sử dụng phổ biến tại hai xã khảo sát là Bidamin 15WP (chứa 15\% hoạt chất PBZ) của Công ty Đồng Xanh và Bonsai 10WP (chứa $10 \%$ hoạt chất $P B Z$ ) của Công ty trách nhiệm hữu hạn Map Pacific. Có 26 hộ nông dân sử dụng sản phẩm thương mại Bidamin 15WP, chiếm $81,3 \%$ tổng số hộ điều tra, chỉ có 1 hộ nông dân sử dụng sản phẩm thương mại Bonsai $10 \mathrm{WP}(3,1 \%)$ và 5 hộ nông dân còn lại sử dụng cả hai sản phẩm thương mại Bidamin 15WP và Bonsai $10 \mathrm{WP}(15,6 \%)$.

Kênh thông tin chính giúp các nông dân ở khu vực điều tra tiếp cận với sản phẩm thương mại chứa hoạt chất $\mathrm{PBZ}$ là sự chia sẻ kinh nghiệm trong nông dân với nhau, chiếm tỉ lệ 62,5\%; đặc biệt ở huyện Phú Tân, tỉnh An Giang, nơi có kinh nghiệm lâu năm trong canh tác lúa và lúa nếp, $34,4 \%$ nông hộ khảo sát biết đến và sử dụng các sản phẩm $\mathrm{PBZ}$ thông qua đại lý bán phân bón và thuốc bảo vệ thực vật và chỉ có $3,1 \%$ nông hộ tiếp cận các sản phẩm PBZ thông qua thông tin trên báo đài.

Nông dân ở khu vực điều tra đã biết đến và sử dụng các sản phẩm thương mại chứa hoạt chất PBZ trong khoảng thời gian dài cho cây lúa nếp và điều này gây tác động tiêu cực đến môi trường sinh thái. Điển hình như nghiên cứu của Reddy and Kurian (2008) cho thấy sản phẩm chứa hoạt chất PBZ ảnh hưởng đến một số đặc tính đất, trong đó có đặc tính sinh học đất nếu sử dụng liên tục trong ba năm. Cụ thể, kết quả khảo sát ở nghiên cứu này cho thấy có đến $59,4 \%$ hộ nông dân được điều tra có thời gian sử dụng các sản phẩm chứa hoạt chất $\mathrm{PBZ}$ trên 10 năm, $25,0 \%$ nông hộ điều tra có thời gian sử dụng từ 5 đến 10 năm và còn lại $15,6 \%$ nông hộ được khảo sát có thời gian sử dụng $\mathrm{PBZ}$ dưới 5 năm.

Có sự khác biệt về tầng suất sử dụng các sản phẩm thương mại chứa hoạt chất $\mathrm{PBZ}$ giữa các hộ nông dân trong 1 vụ canh tác lúa và lúa nếp, dao động từ 1 đến 7 lần/vụ. Theo đó, có 31,3\% hộ được điều tra sử dụng $\mathrm{PBZ} 1$ lần/vụ, sử dụng $\mathrm{PBZ}$ với tần suất 3 lần/vụ chiếm $31,25 \%$ tổng số hộ điều tra. Ngoài ra, có $15,6 \%$ số hộ điều tra có tầng suất sử dụng các sản phẩm chứa $\mathrm{PBZ} 2$ lần/vụ. Bên cạnh đó, có $9,38 \%$ nông hộ khảo sát sử dụng $\mathrm{PBZ}$ với tần suất 4 lần/vụ và $9,4 \%$ sử dụng 5 lần/vụ. Có 1 hộ cá biệt trong tổng số 32 hộ được điều tra sử dụng các sản phẩm thương mại chứa PBZ lên đến 7 lần/vụ, chiếm 3,13\% trong tổng số hộ được khảo sát. Như vậy, tầng suất sử dụng các sản phẩm thương mại chứa hoạt chất $\mathrm{PBZ}$ cho cây lúa và cây nếp ở khu vực khảo sát phổ biến nhất là 1-3 lần/vụ. 
Bảng 2. Kết quả điều tra tình hình sử dụng hoạt chất PBZ trên cây lúa nếp tại xã Bình Mỹ và xá Bình Chánh, huyện Châu Phú, tỉnh An Giang, 7/2020

\begin{tabular}{|c|c|}
\hline Tiêu chí khảo sát & Kết quả khảo sát \\
\hline \multirow{2}{*}{ Loại cây trồng sử dụng PBZ } & Nếp $(78,1 \%)$ \\
\hline & Lúa $(21,9 \%)$ \\
\hline \multirow{3}{*}{ Các sản phẩm thương mại } & Bidamin 15 WP $(81,3 \%)$ \\
\hline & Bonsai $10 \mathrm{WP}(3,1 \%)$ \\
\hline & Bidamin $15 \mathrm{WP}+$ Bonsai $10 \mathrm{WP}(15,6 \%)$ \\
\hline \multirow{3}{*}{ Cách tiếp cận PBZ } & Nông dân $(62,5 \%)$ \\
\hline & Đại lý $(34,4 \%)$ \\
\hline & Báo đài $(3,1 \%)$ \\
\hline \multirow{3}{*}{ Kinh nghiệm sử dụng PBZ } & Dưới 5 năm $(15,6 \%)$ \\
\hline & 5 đến 10 năm $(25,0 \%)$ \\
\hline & trên 10 năm $(59,4 \%)$ \\
\hline Tần suất sử dụng PBZ/vụ & $\begin{array}{l}1 \text { lần }(31,3 \%), 2 \text { lần }(15,6 \%), 3 \text { lần }(31,3 \%), 4 \text { lần }(9,4 \%), 5 \text { lần } \\
(9,4 \%), 7 \text { lần }(3,1 \%)\end{array}$ \\
\hline \multirow{3}{*}{ Thời điểm sử dụng } & Mạ (10-20 NSS) $(78,1 \%)$ \\
\hline & Đẻ nhánh (20-35 NSS) (75\%) \\
\hline & Làm đòng (40-55 NSS) $(53,1 \%)$ \\
\hline \multirow{2}{*}{ Liều lượng } & Thấp hơn khuyến cáo $(6,3 \%)$ \\
\hline & Cao hơn khuyến cáo $(93,7 \%)$ \\
\hline \multirow{3}{*}{$\begin{array}{l}\text { Hiểu biết của nông dân về độ an } \\
\text { toàn và tính độc của các sản phẩm } \\
\text { PBZ }\end{array}$} & Không độc, tiếp tục sử dụng $(34,4 \%)$ \\
\hline & Độc, nhưng tiếp tục sử dụng $(34,4 \%)$ \\
\hline & Độc, tìm sản phâm khác để thay thế $(31,2 \%)$ \\
\hline
\end{tabular}

Kết quả điều tra cho thấy có 3 thời điểm phổ biến khi nông dân bón $\mathrm{PBZ}$ cho cây lúa và cây nếp tại hai xã Bình Mỹ và Bình Chánh, huyện Châu Phú, tỉnh An Giang là 10-20 NSS, 20-35 NSS và 40-45 NSS. Theo đó, nông dân bắt đầu sử dụng $\mathrm{PBZ}$ vào thời điểm 10 NSS và kéo dài đến giai đoạn trổ bông (khoảng 55 NSS). Vì đây là giai đoạn cây tăng trưởng mạnh, cây phát triển về thân lá, chiều cao tăng dần và hình thành nhiều chồi mới nên nông dân đã chọn thời điểm này để bón các sản phẩm thương mại chứa hoạt chất $\mathrm{PBZ}$ nhằm khống chế chiều cao cây, chống đổ ngã, thúc đẩy cây đẻ nhánh và nở bụi. Trong đó, có 78,1\% hộ điều tra đã sử dụng PBZ ở giai đoạn mạ (10 đến $22 \mathrm{NSS}$ ), $75 \%$ nông dân khảo sát bón $\mathrm{PBZ}$ vào thời điểm 20 đến $35 \mathrm{NSS}$ và $53,1 \%$ số hộ khảo sát sử dụng $\mathrm{PBZ}$ vào thời điểm 40 đến 55 NSS.

Kết quả điều tra liều lượng sử dụng các sản phẩm thương mại chứa hoạt chất PBZ cho thấy $93,7 \%$ nông hộ được điều tra sử dụng các sản phẩm PBZ với nồng độ cao hơn so với nồng độ khuyến cáo $\left(0,012 \mathrm{~kg} / 1000 \mathrm{~m}^{2} / \mathrm{vu}\right)$ và $6,3 \%$ số hộ điều tra sử dụng PBZ thấp hơn so với nồng độ khuyến cáo. Cụ thể, 33,3\% số hộ sử dụng $\mathrm{PBZ}$ cao hơn từ 1,25-5 lần và 6-10 lần so với khuyến cáo. Tiếp theo có $16,7 \%$ số hộ sử dụng lượng PBZ cao hơn so với khuyến cáo gấp 11-15 lần, 13,3\% sử dụng $\mathrm{PBZ}$ cao hơn khuyến cáo 16-20 lần. Đặc biệt, có 1 hộ sử dụng PBZ có nồng độ cao hơn khuyến cáo lên đến 20 lần và chiếm $3,34 \%$. Do đó, lưu tồn về PBZ trong đất qua các vụ canh tác đã ức chế sự sinh trưởng và phát triển của cây lúa nếp làm cho cây bị còi cọc và ảnh hưởng đến năng suất (Hình 1).

Kết quả khảo sát về mức độ hiểu biết của nông dân ở hai xã Bình Mỹ và Bình Chánh, huyện Châu Phú, tỉnh An Giang về độ an toàn và độc tính của các sản phẩm thương mại chứa hoạt chất $\mathrm{PBZ}$ sử dụng cho cây lúa nếp đến môi trường sinh thái và sức khỏe cho thấy trong tổng số 32 hộ nông dân được điều tra có $34,4 \%$ số hộ cho rằng các sản phẩm chứa hoạt chất PBZ không gây ảnh hưởng tiêu cực lên cây trồng. Trong khi đó, $34,4 \%$ nông dân cho rằng các sản phẩm thương mại chứa hoạt chất $\mathrm{PBZ}$ có tác động không tốt đối với cây trồng, đất đai và môi trường thông qua các biểu hiện của cây trồng như làm cho cây lúa và lúa nếp bị vàng lá, còi cọc, từ đó nông dân phải tăng cường bón lượng phân bón hóa học qua mỗi năm canh tác để đảm bảo năng suất cho cây lúa nếp. Tuy nhiên, họ vẫn muốn tiếp tục sử dụng trong tương lai vì chưa tìm được sản phẩm thay thế có cùng chức năng nhưng thân thiện cho môi trường sinh thái. Ngoài ra, $31,2 \%$ số hộ nông dân còn lại hiểu được những mối nguy hại của sản phẩm thương mại chứa hoạt chất PBZ đối với cây trồng, đất đai và môi trường nên sẽ tạm ngưng sử dụng và tìm kiếm các sản phẩm khác có hiệu quả tốt trong 
việc giảm chiều cao cây lúa nếp nhưng ít độc cây trồng và môi trường.

Kết quả khảo sát tình hình sử dụng các sản phẩm thương mại chứa hoạt chất $\mathrm{PBZ}$ của các hộ nông dân canh tác lúa và lúa nếp ở hai xã Bình Mỹ và Bình Chánh, huyện Châu Phú, tỉnh An Giang cho thấy nông dân ở khu vực này sử dụng các sản phẩm thương mại chứa $\mathrm{PBZ}$ với liều lượng rất cao để hạn chế sự phát triển chiều cao cây lúa nếp nhằm chống đổ ngã, tuy nhiên điều này không đồng nghĩa với việc năng suất cây lúa nếp được tăng lên mà có xu hướng giảm xuống. Bên cạnh đó, việc sử dụng PBZ với liều lượng quá cao bước đầu đã gây ra các tác động tiêu cực đến hệ sinh thái nông nghiệp, cây lúa nếp bị còi cọc, không thể trổ bông và cần phải tăng lượng phân qua mỗi năm canh tác nhằm đảm bảo năng suất cây nếp do hàm lượng $\mathrm{PBZ}$ lưu tồn trong đất tích lũy ngày càng cao theo thời gian sử dụng $\mathrm{PBZ}$. Điều này hoàn toàn phù hợp vì nghiên cứu của Silva et al. (2003) cho thấy việc sử dụng PBZ ở nồng độ cao trong ruộng lúa sẽ làm ảnh hưởng xấu đến cộng đồng vi sinh vật trong đất như mật số vi khuẩn, nấm và xạ khuẩn sẽ giảm lần lượt $58 \%, 28 \%$ và $28 \%$ và giảm hoạt động của enzyme dehydrogenase. Ngoài ra, MDAR (2012) cho rằng gốc chlor trong $\mathrm{PBZ}$ có độc tính cao, do đó, ảnh hưởng đến các sinh vật trong đất trong đó có nhóm vi sinh vật đất, thực vật và cả con người.

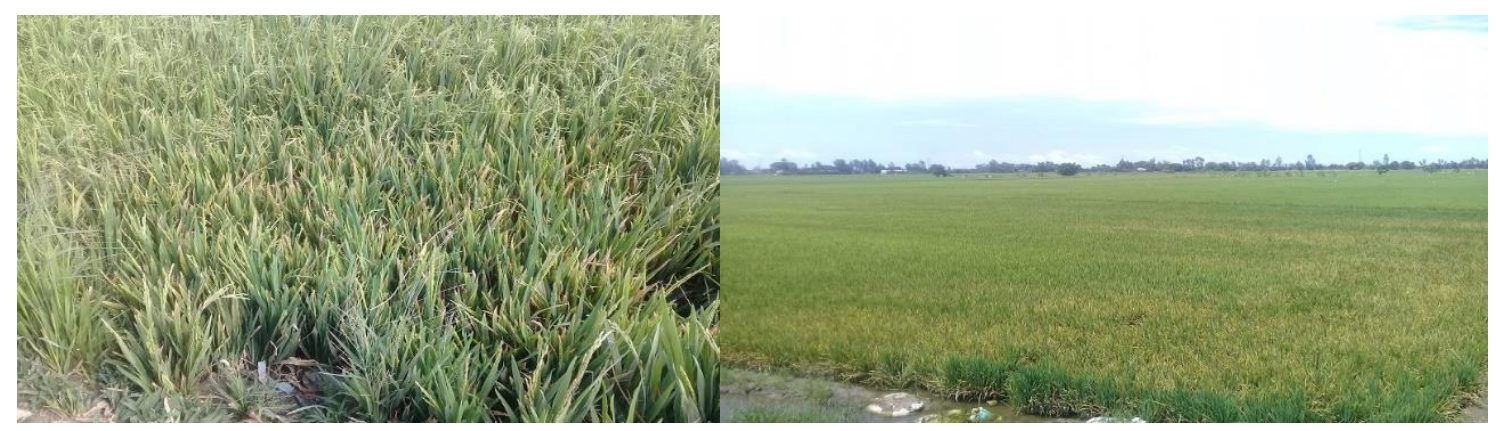

Hình 1. Ảnh hưởng của việc sử dụng sản phẩm thương mại chứa hoạt chất $\mathrm{PBZ}$ đến sinh trưởng của cây lúa nếp ở xã Bình Mỹ, huyện Châu Phú, tỉnh An Giang (7/2020)

3.2. Lưu tồn $P B Z$ trong 10 mẫu đất canh tác lúa nếp ở huyện Châu Phú, tỉnh An Giang

Thông tin 10 nông hộ được chọn để thu mẫu đất nhằm đánh giá mức độ lưu tồn hoạt chất $\mathrm{PBZ}$ trong đất do sử dụng hoạt chất $\mathrm{PBZ}$ nhiều nhất trong tổng số 32 hộ nông dân được khảo sát tại huyện Châu Phú, tỉnh An Giang được trình bày trong Bảng 3 .

Bảng 3. Thông tin 10 nông hộ được chọn để phân tích hàm lượng PBZ lưu tồn trong đất tại huyện Châu Phú, tỉnh An Giang (7/2020)

\begin{tabular}{llrrr}
\hline $\begin{array}{l}\text { Code } \\
\text { mẫu đất }\end{array}$ & Loại cây & $\begin{array}{r}\text { Lượng sử dụng sản phẩm thương } \\
\text { mại chứa } \mathbf{P B Z} \\
\left(\mathbf{g} / \mathbf{v u ̣ / 1 . 0 0 0} \mathbf{~ m}^{\mathbf{2}}\right)\end{array}$ & $\begin{array}{r}\text { Lịch sử sử dụng PBZ } \\
(\mathbf{n a ̆ m})\end{array}$ & $\begin{array}{r}\text { Số lần/vụ } \\
\text { CP1-5 }\end{array}$ Nếp \\
CP2-6 & Nếp & 500 & 5 & 3 \\
CP3-10 & Nếp & 1.000 & 6 & 3 \\
CP4-10 & Nếp & 600 & 10 & 3 \\
CP5-10 & Nếp & 1.000 & 10 & 2 \\
CP6-10 & Nếp & 1.000 & 10 & 1 \\
CP7-6 & Nếp & 1.000 & 10 & 1 \\
CP8-10 & Nếp & 900 & 6 & 4 \\
CP9-2 & Nếp & 800 & 10 & 3 \\
CP10-6 & Nếp & 550 & 2 & 10 \\
\hline
\end{tabular}

*Cách đặt tên mẫu đất được thực hiện theo quy uớc sau: CP là địa điểm thu mẫu đất và các số theo sau hiển thị cho thời gian sử dụng hoụt chất PBZ trên ruộng nếp trong quá trình canh tác.

Kết quả phân tích hàm lượng PBZ lưu tồn trong đất trồng lúa nếp của 10 hộ nông dân sử dụng PBZ nhiều nhất ở khu vực khảo sát tại hai xã Bình Mỹ và
Bình Chánh, huyện Châu Phú, tỉnh An Giang được trình bày trong Hình 2. 


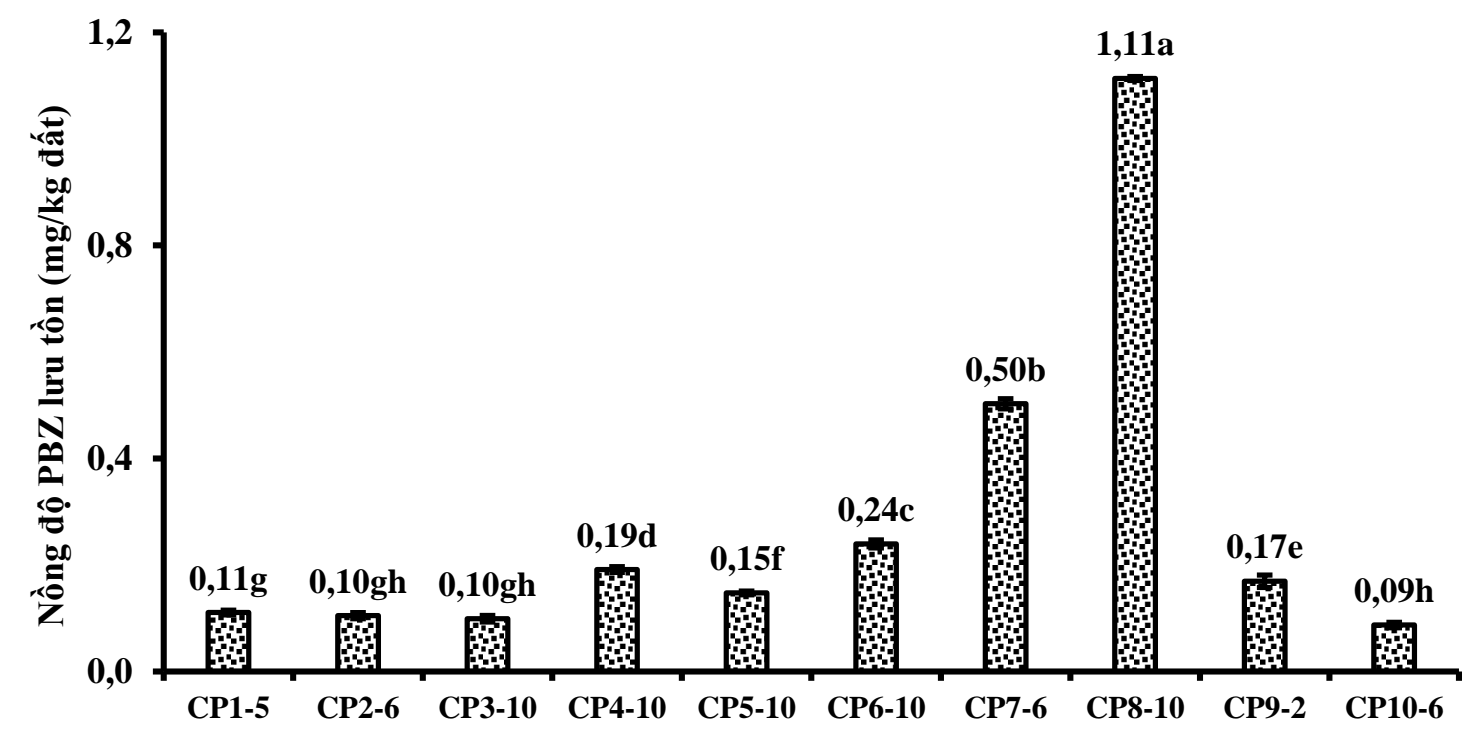

Nghiệm thức

Hình 2. Nồng độ PBZ lưu tồn trong 10 mẫu đất trồng lúa nếp tại huyện Châu Phú, tỉnh An Giang (7/2020)

Kết quả phân tích cho thấy tất cả 10 mẫu đất được thu ở tầng đất $0-20 \mathrm{~cm}$ tại các địa điểm được chọn đều phát hiện nồng độ lưu tồn PBZ trong đất và dao động từ $0,09 \mathrm{mg} / \mathrm{kg}$ đất đến $1,11 \mathrm{mg} / \mathrm{kg}$ đất qua phân tích mẫu trên máy HPLC. Mẫu CP8-10 có hàm lượng $\mathrm{PBZ}$ lưu tồn trong đất nhiều nhất với nồng độ đạt $1,11 \mathrm{mg} / \mathrm{kg}$ đất và đây cũng là mẫu đất thu ở ruộng có thời gian sử dụng PBZ là 10 năm với liều lượng $800 \mathrm{~g} / 1.000 \mathrm{~m}^{2} / \mathrm{vụ} \mathrm{và} \mathrm{thực} \mathrm{hiện} \mathrm{bón} 3$ lần/vụ. Kể đến là mẫu đất ký hiệu CP7-6 có nồng độ PBZ lưu tồn trong đất được phát hiện là $0,50 \mathrm{mg} / \mathrm{kg}$ đất. Đây cũng là mẫu đất thu từ ruộng trồng lúa nếp của nông dân có thời gian sử dụng PBZ là 6 năm với liều lượng $900 \mathrm{~g} / 1000 \mathrm{~m}^{2} / \mathrm{vụ} \mathrm{và} \mathrm{tầng} \mathrm{suất} \mathrm{bón} 4$ lần/vụ. Nồng độ $\mathrm{PBZ}$ thấp nhất được tìm thấy trong 3 mẫu đất ký hiệu $\mathrm{CP} 10-6, \mathrm{CP} 2-6$ và $\mathrm{CP} 3-10$ tương ứng với hàm lượng $\mathrm{PBZ}$ lưu tồn trong đất là 0,09 , 0,10 và $0,10 \mathrm{mg} / \mathrm{kg}$ đất. Ba mẫu đất này được thu trên 3 ruộng trồng nếp có thời gian sử dụng lần lượt là 6 năm, 6 năm và 10 năm với liều lượng $800 \mathrm{~g} / \mathrm{vụ}$, $1.000 \mathrm{~g} / \mathrm{vụ} \mathrm{và} 600 \mathrm{~g} / \mathrm{vụ}$. Kết quả còn cho thấy nồng độ $\mathrm{PBZ}$ lưu tồn trong đất cao hơn ở các ruộng có lịch sử sử dụng PBZ 6-10 năm so với các mẫu đất thu ở các ruộng có lịch sử sử dụng PBZ ở thời gian từ 2-6 năm. Điều này cho thấy nồng độ $\mathrm{PBZ}$ lưu tồn trong đất có $\mathrm{xu}$ hướng tăng dần theo thời gian sử dụng PBZ.
3.3. Đánh giá hiệu quả của chế phẩm vi khuẩn chứa các dòng vi khuẩn phân hủy PBZ lên lưu tồn PBZ trong đất trồng lúa nếp, sinh trưởng và năng suất lúa nếp tại huyện Châu Phú, tỉnh An Giang

\subsubsection{Luu tồn PBZ trong đất}

Kết quả phân tích hàm lượng $\mathrm{PBZ}$ trong đất của các nghiệm thức thí nghiệm được trình bày trong Bảng 4 cho thấy có sự khác biệt giữa các nghiệm thức thí nghiệm $(\mathrm{p}<0,05)$ về nồng độ $\mathrm{PBZ}$ lưu tồn trong đất. Đồng thời, không phát hiện hoạt chất PBZ lưu tồn trong đất trồng lúa nếp ở độ sâu $0-20 \mathrm{~cm}$ của các nghiệm thức có sử dụng chế phẩm vi khuẩn qua hai thời điểm. Cụ thể, ở thời điểm 35 NSS (sau 10 ngày kể từ thời điểm nông dân bón hoạt chất PBZ vào đất), nghiệm thức bón phân NPK theo nông dân (đối chứng) và nghiệm thức bón phân NPK kết hợp bón phân hữu cơ (2 tấn/ha) có nồng độ hoạt chất PBZ lưu tồn trong đất đều đạt $0,13 \mathrm{mg} / \mathrm{kg}$ đất khô, trong khi đó hai nghiệm thức có sử dụng chế phẩm vi sinh gồm nghiệm thức bón NPK kết hợp phun chế phẩm vi sinh và nghiệm thức sử dụng NPK kết hợp bón phân hữu cơ 2 tấn/ha và phun chế phẩm vi sinh có nồng độ PBZ trong đất thấp ở ngưỡng không phát hiện. 
Đến thời điểm thu hoạch (105 NSS), nồng độ PBZ trong đất ở hầu hết các nghiệm thức thí nghiệm ở ngưỡng thấp. Cụ thể các nghiệm thức gồm: nghiệm thức bón phân NPK kết hợp bón phân hữu cơ (2 tấn/ha), nghiệm thức bón phân NPK kết hợp phun chế phẩm vi sinh và nghiệm thức bón NPK kết hợp bón phân hữu cơ (2 tấn/ha) và chế phẩm vi sinh đều không phát hiện PBZ lưu tồn trong đất. Trong khi đó, nghiệm thức chỉ bón phân NPK theo nông dân có nồng độ $\mathrm{PBZ}$ lưu tồn ở mức $0,13 \mathrm{mg} / \mathrm{kg}$ đất. Đồng thời hệ số biến thiên giữa các nghiệm thức (CV) rất cao, đạt $175,99 \%$, chứng tỏ có sự khác biệt rất lớn giữa nghiệm thức đối chứng (chỉ bón phân NPK theo nông dân) và các nghiệm thức có sử dụng chế phẩm vi khuẩn phân hủy PBZ hoặc bón phân hữu cơ. Qua đó có thể thấy, việc bón phân hữu cơ hoặc phun chế phẩm vi sinh đều có khả năng giúp phân hủy hoạt chất $\mathrm{PBZ}$ lưu tồn trong nền đất trồng lúa nếp, tuy nhiên tốc độ phân hủy hoạt chất PBZ của nghiệm thức bón chế phẩm vi sinh nhanh hơn nghiệm thức bón phân hữu cơ và đây là yếu tố then chốt giúp thực hiện chức năng làm giảm thiểu lưu tồn của PBZ trong đất.

Bảng 4. Hàm lượng PBZ lưu tồn trong đất của các nghiệm thức thí nghiệm tại huyện Châu Phú, tỉnh An Giang (12/2020)

\begin{tabular}{lrr}
\hline \multirow{2}{*}{ Nghiệm thức } & \multicolumn{2}{c}{ Nồng độ PBZ lưu tồn (mg/kg đất) } \\
\cline { 2 - 3 } & 30 ngày sau sạ (NSS) & Thu hoạch (105 NSS) \\
\hline Đối chứng (NPK nông dân) & $0,13^{\mathrm{a}}$ & $0,13^{\mathrm{a}}$ \\
NPK + PHC & $0,13^{\mathrm{a}}$ & $0^{\mathrm{b}}$ \\
$\mathrm{NPK}+\mathrm{Vi}$ sinh & $0^{\mathrm{b}}$ & $0^{\mathrm{b}}$ \\
$\mathrm{NPK}+\mathrm{PHC}+\mathrm{Vi}$ sinh & $0^{\mathrm{b}}$ & $0^{\mathrm{b}}$ \\
\hline F & $*$ & $*$ \\
$\mathrm{CV}(\%)$ & 106,06 & 175,99 \\
\hline
\end{tabular}

*Ghi chú: NSS: ngày sau sạ; * là khác biệt ý nghĩa thống kê ở giũa các nghiệm thức ở mức ý nghĩa 5\% theo phép thủ Tukey và trong cùng một cột các số có chũ theo sau giống nhau thì không khác biệt ý nghĩa thống kê ớ 5\%; ns: không khác biệt thống kê

\subsubsection{Chiều cao cây và số chồi}

Nhìn chung, chiều cao cây và số chồi của cây nếp không khác biệt ý nghĩa thống kê $(\mathrm{p}>0,05)$ giữa các nghiệm thức ở hầu hết các thời điểm khảo sát (Hình 3). Cụ thể ở thời điểm $30 \mathrm{NSS}$, chiều cao cây lúa nếp ở nghiệm thức bón NPK khuyến cáo kết hợp phân hữu cơ và chế phẩm vi khuẩn có chiều cao cây cao nhất và đạt $51,5 \mathrm{~cm}$, khác biệt ý nghĩa thống kê khi so với nghiệm thức đối chứng chỉ bón NPK $(43,4$ $\mathrm{cm})(\mathrm{p}<0,05)$ theo phép thử Tukey, tuy nhiên không khác biệt khi so với nghiệm thức bón NPK kết hợp bón phân hữu cơ $(48 \mathrm{~cm})$ hoặc nghiệm thức bón NPK kết hợp phun chế phẩm vi khuẩn $(48,8 \mathrm{~cm})$

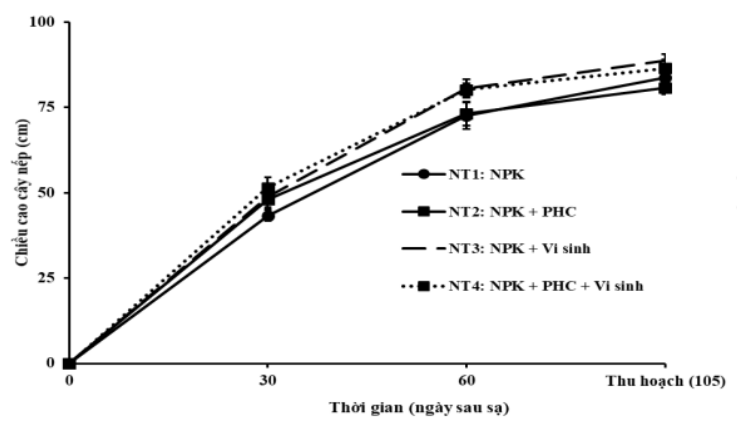

$(\mathrm{p}>0,05)$ và $\mathrm{xu}$ hướng này được duy trì đến thời điểm 60 NSS. Đến thời điểm thu hoạch (105 NSS), nghiệm thức bón NPK kết hợp phun chế phẩm vi khuẩn có chiều cao cây đạt $88,6 \mathrm{~cm}$, cao nhất và khác biệt ý nghĩa thống kê so với ngiệm thức bón NPK kết hợp bón phân hữu cơ $(p<0,05)$, tuy nhiên không khác biệt ý nghĩa thống kê $(p>0,05)$ so với nghiệm thức đối chứng NPK và nghiệm thức NPK kết hợp bón phân hữu cơ và chế phẩm vi khuẩn. Như vậy, việc bón phân NPK theo khuyến cáo kết hợp phun chế phẩm vi khuẩn chứa các dòng vi khuẩn phân hủy PBZ không những giúp giảm nồng độ hoạt chất PBZ lưu tồn trong đất mà còn giúp tăng chiều cao cây lúa nếp ở điều kiện thực tế đồng ruộng.

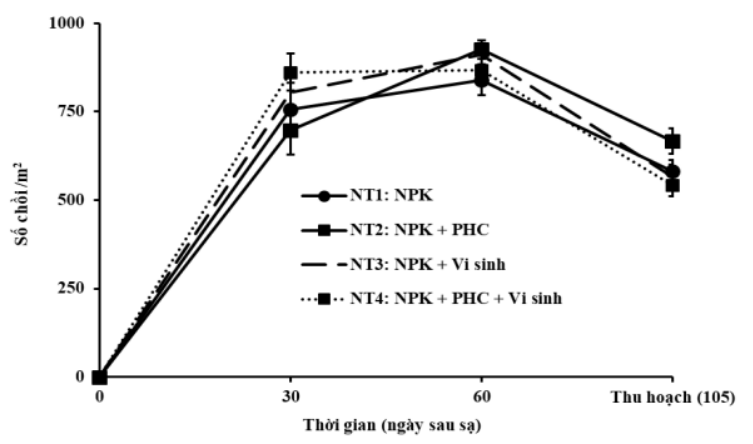

Hình 3. Chiều cao cây và số chồi cây lúa nếp ở các nghiệm thức thí nghiệm qua các thời điểm khảo sát 
Tương tự, số chồi cây lúa nếp giữa các nghiệm thức cũng không có sự khác biệt rõ qua hầu hết các thời điểm khảo sát, trong đó ở thời điểm 60 NSS, nghiệm thức bón NPK kêt hợp sử dụng phân hữu cơ 2 tấn/ha có số chồi cao nhất $\left(926\right.$ chồi $\left./ \mathrm{m}^{2}\right)$ và khác biệt ý nghĩa thống kê $(\mathrm{p}<0,05)$ khi so với nghiệm thức đối chứng bón NPK ( 840 chồi $\left./ \mathrm{m}^{2}\right)$, tuy nhiên khác biệt không có ý nghĩa so với số chồi của 2 nghiệm thức có sử dụng chế phẩm vi khuẩn. Đến thời điểm thu hoạch (105 NSS), số chồi của nghiệm thức chỉ sử dụng phân hữu cơ tiếp tục đạt cao nhất, đồng thời khác biệt thống kê $(\mathrm{p}<0,05)$ so với tất cả các nghiệm thức còn lại. Như vậy, việc bón phân NPK kết hợp bón phân hữu cơ 2 tân/ha giúp gia tăng số chồi lúa nếp ở thực tế đồng ruộng.

\subsubsection{Thành phần năng suất lúa nếp}

Kết quả khảo sát thành phần năng suất lúa nếp ở các thí nghiệm được trình bày trong Bảng 5 cho thấy nhìn chung có sự khác biệt về thành phần năng suất lúa nếp giữa các nghiệm thức thí nghiệm khi so sánh với nhau. Cụ thể, số bông ở nghiệm thức bón NPK kết hợp phun chế phẩm vi khuẩn và bón 2 tấn/ha phân hữu cơ đạt số bông cao nhất (542 bông $/ \mathrm{m}^{2}$ ), khác biệt ý nghĩa thống kê so với nghiệm thức đối chứng bón NPK (467 bông $/ \mathrm{m}^{2}$ ) ở mức ý nghĩa $5 \%$ theo phép thử Tukey $(\mathrm{p}<0,05)$, tuy nhiên không khác biệt ý nghĩa thống kê $(\mathrm{p}>0,05)$ khi so sánh với hai nghiệm thức: bón NPK kết hợp bón phân hữu cơ hoặc NPK kết hợp phun chế phẩm vi khuẩn và đồng thời hai nghiệm thức này khác biệt không có ý nghĩa thống kê $(\mathrm{p}>0,05)$ khi so sánh với nghiệm thức đối chứng bón NPK.

Chiều dài bông ở tất cả các nghiệm thức bón phân hữu cơ, phun chế phẩm vi khuẩn và sử dụng kết hợp phân hữu cơ và chế phẩm vi khuẩn trên nền phân bón hóa học NPK theo khuyến cáo đều cao hơn và khác biệt ý nghĩa thống kê $(\mathrm{p}<0,05)$ ở mức $5 \%$ so với nghiệm thức đối chứng chỉ bón NPK $(18,6 \mathrm{~cm})$ với chỉ tiêu về chiều dài bông của các nghiệm thức này lần lượt đạt $20,5 \mathrm{~cm}, 21,6 \mathrm{~cm}$ và $21,6 \mathrm{~cm}$. Đồng thời, chiều dài bông ở ba nghiệm thức này khác biệt không ý nghĩa thống kê khi so sánh với nhau theo phép thử Tukey $(\mathrm{p}>0,05)$.

\section{Bảng 5. Thành phần năng suất của các nghiệm thức thí nghiệm trên lúa nếp ngoài đồng tại huyện Châu Phú, tỉnh An Giang}

\begin{tabular}{|c|c|c|c|c|}
\hline Nghiệm thức & Số bông/m² & $\begin{array}{r}\text { Chiều dài bông } \\
(\mathrm{cm})\end{array}$ & Số hạt/bông & $\begin{array}{r}\text { Tỷ lệ hạt } \\
\text { chắc/bông }(\%)\end{array}$ \\
\hline Đối chứng (NPK nông dân) & $467^{b}$ & $18,6^{\mathrm{b}}$ & $85,1^{\mathrm{b}}$ & $61,2^{b}$ \\
\hline $\mathrm{NPK}+\mathrm{PHC}$ & $522^{\mathrm{ab}}$ & $20,5^{\mathrm{a}}$ & $84,6^{\mathrm{b}}$ & $67,8^{\mathrm{a}}$ \\
\hline NPK + Vi sinh & $516^{\mathrm{ab}}$ & $21,6^{\mathrm{a}}$ & $89,1^{\text {a }}$ & $60,3^{\mathrm{b}}$ \\
\hline $\mathrm{NPK}+\mathrm{PHC}+\mathrm{Vi} \sinh$ & $542^{\mathrm{a}}$ & $21,6^{\mathrm{a}}$ & $89,1^{\mathrm{a}}$ & $68,7^{\mathrm{a}}$ \\
\hline $\mathrm{F}$ & * & $*$ & * & * \\
\hline $\mathrm{CV}(\%)$ & 7,60 & 6,85 & 2,97 & 6,52 \\
\hline
\end{tabular}

*Ghi chú: * là khác biệt ý nghĩa thống kê giũa các nghiệm thức ở múc ý nghĩa 5\% theo phép thử Tukey và trong cùng một cột các số có chũ theo sau giống nhau thi không khác biệt ý nghĩa thống kê ớ 5\%; ns: khác biệt không ý nghĩa thống $k \hat{e}$

Hai nghiệm thức có sử dụng chế phẩm vi khuẩn có số hạt trền bông cao hơn và khác biệt ý nghĩa thống kê so với hai nghiệm thức còn lại $(\mathrm{p}<0,05)$. Cụ thể nghiệm thức phun chế phẩm vi khuẩn và nghiệm thức phun chế phẩm vi khuẩn kết hợp với bón phân hữu cơ 2 tấn/ha có số hạt trên bông cao nhất và đều đạt 89,1 hạt/bông, khác biệt ý nghĩa thống kê so với nghiệm thức đối chứng chỉ bón NPK (85,1 hạt/bông) và nghiệm thức bón NPK kết hợp bón phân hữu cơ (84,6 hạt/bông). Tuy nhiên, hai nghiệm thức có sử dụng phân hữu cơ 2 tấn/ha có tỷ lệ hạt chắc/bông cao hơn và khác biệt ý nghĩa thống kê $(p<0,05)$ khi so sánh với nghiệm thức bón NPK kết hợp chế phẩm vi khuẩn và nghiệm thức đối chứng bón NPK. Cụ thể nghiệm thức sử dụng phân hữu cơ 2 tấn/ha có tỷ lệ hạt chắc/bông đạt cao nhất
(67,8\%), không khác biệt ý nghĩa thống kê ( $>>0,05)$ khi so với nghiệm thức bón NPK kết hợp chế phẩm vi khuẩn và phân hữu cơ $(68,7 \%)$, đồng thời hai nghiệm thức này có tỉ lệ hạt chắc/bông cao hơn và khác biệt ý nghĩa thống kê ở mức $5 \%(\mathrm{p}<0,05)$ khi so sánh với nghiệm thức đối chứng bón NPK $(61,2 \%)$ và nghiệm thức bón NPK kết hợp phun chế phẩm vi khuẩn phân hủy hoạt chất PBZ $(60,3 \%)$.

\subsubsection{Sinh khối khô, năng suất lý thuyết và thực tế}

Sinh khối rơm của các nghiệm thức thí nghiệm được trình bày trong Hình 4 cho thấy các nghiệm thức có sinh khối rơm dao động từ 7,11 tấn.ha ${ }^{-1}$ đến 8,91 tấn.ha- ${ }^{-1}$ và khác biệt ý nghĩa thống kê khi so sánh với nhau $(\mathrm{p}<0,05)$. Cụ thể, nghiệm thức sử 
dụng NPK kết hợp phân hữu cơ (2 tấn.ha $\left.a^{-1}\right)$ và chế phẩm vi khuẩn $\left(5\right.$ lít $\left./ 1.000 \mathrm{~m}^{2}\right)$ có sinh khối rơm đạt cao nhất với 8,91 tấn.ha-1 ${ }^{-1}$, không khác biệt ý nghĩa thống kê so với nghiệm thức đối chứng bón NPK với 8,28 tấn.ha ${ }^{-1}(p>0,05)$. Cao thứ 2 là nghiệm thức bón NPK kết hợp phun chế phẩm vi khuẩn với 7,87 tấn.ha ${ }^{-1}$ và thấp nhất là nghiệm thức bón NPK kết hợp bón phân hữu cơ 2 tấn/ha với sinh khối khô đạt 7,11 tấn.ha ${ }^{-1}$, khác biệt ý nghĩa thống kê so với các nghiệm thức còn lại $(\mathrm{p}<0,05)$ theo phép thử Tukey.

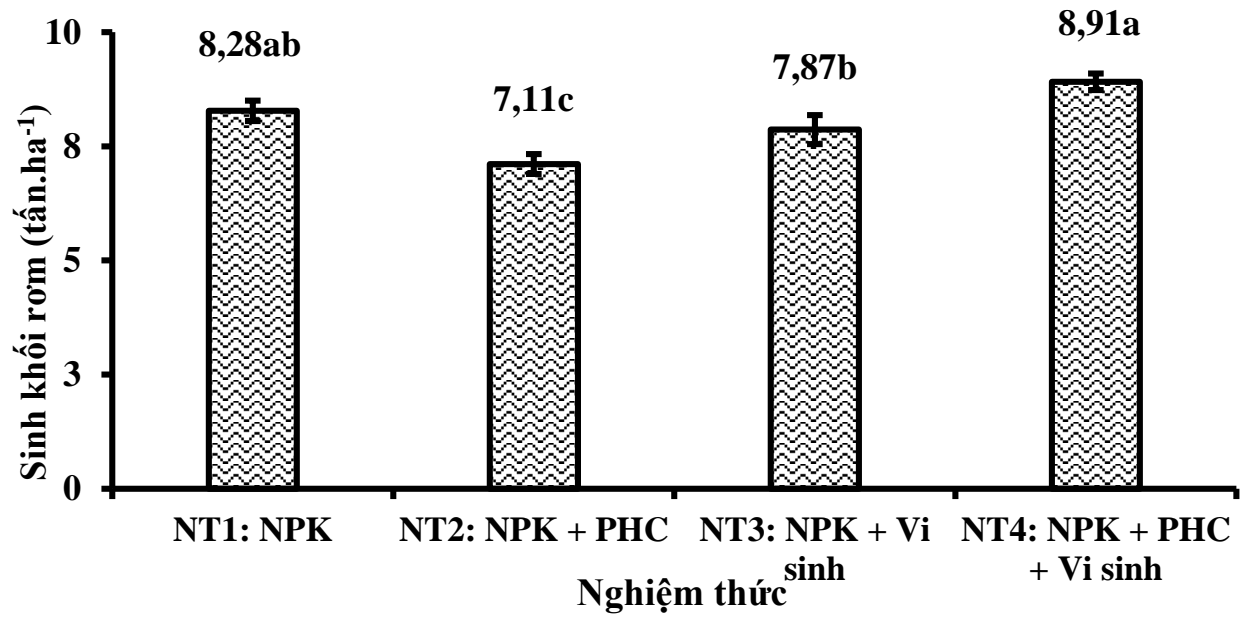

Hình 4. Sinh khối khô của các nghiệm thức thí nghiệm lúa nếp tại huyện Châu Phú, tỉnh An Giang

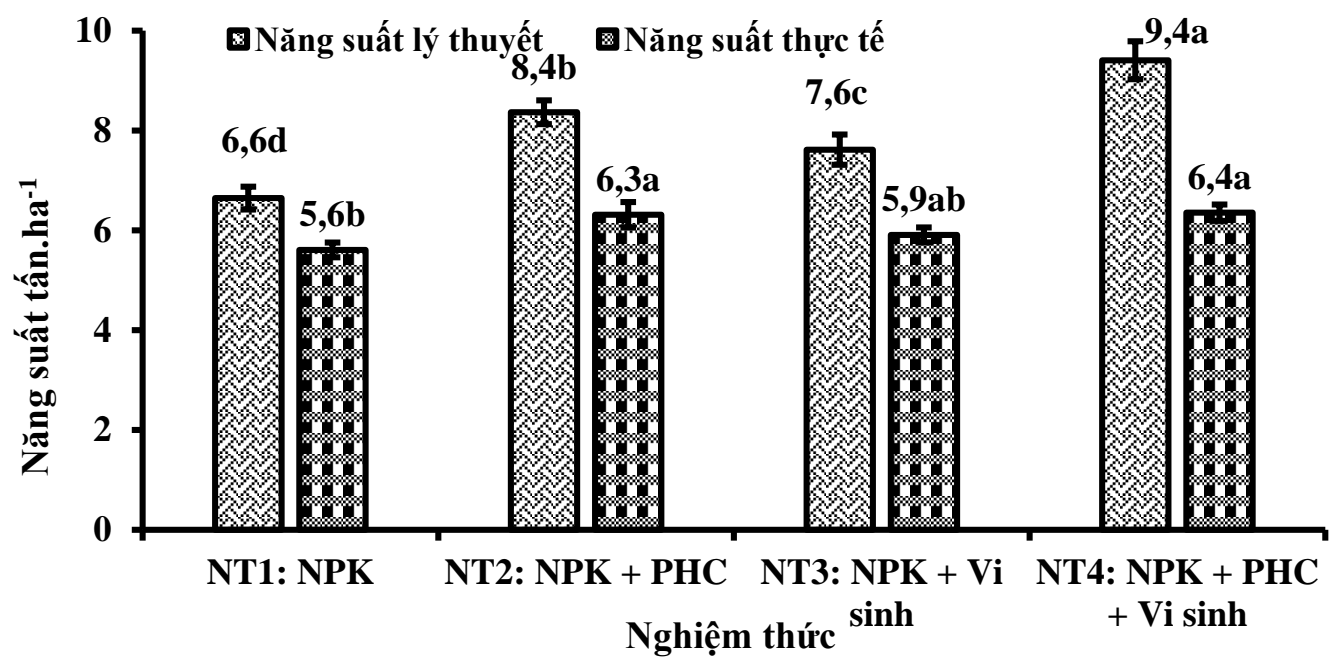

Hình 5. Năng suất lý thuyết và năng suất thực tế của lúa nếp ở các nghiệm thức thí nghiệm tại huyện Châu Phú, tỉnh An Giang

Năng suất lý thuyết và năng suất thực tế của các nghiệm thức thí nghiệm ngoài đồng được trình bày trong Hình 5 cho thấy các nghiệm thức có năng suất lý thuyết dao động 6,6-9,4 tấn.ha-1 và năng suất thực tế dao động 5,6-6,4 tấn.ha-1 . Bên cạnh đó, có sự khác biệt ý nghĩa thống kê $(\mathrm{p}<0,05)$ khi so sánh năng suất lý thuyết hoặc năng suất thực tế giữa các nghiệm thức với nhau.

Cụ thể, năng suất lý thuyết của nghiệm thức bón NPK, kết hợp chế phẩm vi khuẩn và bón phân hữu cơ 2 tấn/ha đạt cao nhất với 9,4 tấn.ha ${ }^{-1}$, khác biệt ý nghĩa thống kê so với tất cả các nghiệm thức còn lại ở mức $5 \%$ theo phép thử Tukey $(\mathrm{p}<0,05)$. Nghiệm thức bón NPK kết hợp bón phân hữu cơ 2 tấn/ha, cao thứ 2 với năng suất lý thuyết đạt 8,4 tấn.ha ${ }^{-1}$, cao thứ 3 là nghiệm thức phun bón NPK kết hợp phun chế phẩm vi khuẩn với 7,6 tấn.ha ${ }^{-1}$ và thấp nhất là nghiệm thức đối chứng bón phân NPK theo nông dân với 6,6 tấn.ha ${ }^{-1}$. Đồng thời, các nghiệm thức này khác biệt ý nghĩa thống kê khi so sánh với nhau ở mức ý nghĩa $5 \%$ theo phép thử Tukey $(\mathrm{p}<0,05)$. 
Năng suất thực tế của 2 nghiệm thức bón NPK kết hợp sử dụng phân hữu cơ 2 tấn/ha và phun chế phẩm vi khuẩn chứa các dòng vi khuẩn phân hủy PBZ và nghiệm thức bón NPK kết hợp bón phân hữu cơ đạt cao nhất với lần lượt là 6,4 tấn.ha ${ }^{-1}$ và 6,3 tấn.ha ${ }^{-1}$, hai nghiệm thức này không khác biệt ý nghĩa thống kê $(\mathrm{p}>0,05)$ khi so sánh với nhau và với nghiệm thức bón NPK kết hợp phun chế phẩm vi khuẩn (năng suất thực tế đạt 5,9 tấn.ha $\left.\mathrm{a}^{-1}\right)(\mathrm{p}>0,05)$, tuy nhiên ba nghiệm thức này khác biệt thống kê khi so sánh với nghiệm thức đối chứng chỉ bón NPK $\left(5,6\right.$ tấn.ha $\left.{ }^{-1}\right)$. Bên cạnh đó, nghiệm thức bón NPK kết hợp sử dụng chế phẩm vi khuẩn và nghiệm thức đối chứng chỉ bón NPK có năng suất thực tế không khác biệt ý nghĩa thống kê khi so sánh với nhau $(\mathrm{p}>0,05)$.

\section{KẾT LUẬN}

Nông dân canh tác lúa nếp ở hai xã Bình Mỹ và Bình Chánh thuộc huyện Châu Phú, tỉnh An Giang sử dụng rất phổ biến và thường xuyên các sản phẩm thương mại chứa hoạt chất $\mathrm{PBZ}$ với liều lượng cao hơn rất nhiều lần so với khuyến cáo cho cây lúa nếp.

Hàm lượng PBZ lưu tồn trong đất canh tác lúa tại các điểm khảo sát ở huyện Châu Phú, tỉnh An Giang khá cao, dao động từ $0,09 \mathrm{mg} / \mathrm{kg}$ đất đến 1,11 $\mathrm{mg} / \mathrm{kg}$ đất.

Chế phẩm vi khuẩn chứa 3 dòng vi khuẩn phân hủy hoạt chất $P B Z$ có ký hiệu CT3-92, B6-1 và B2$\mathrm{O}$ phân hủy tốt hoạt chất $\mathrm{PBZ}$ lưu tồn trong đất trồng lúa nếp sau 1 vụ canh tác ở thực tế đồng ruộng, ngoài ra chế phẩm vi khuẩn còn giúp gia tăng chiều cao cây và sinh khối khô cây lúa nếp ở điều kiện thực tế đồng ruộng, tuy nhiên chưa giúp gia tăng năng suất lúa nếp qua 1 vụ canh tác khi so với nghiệm thức đối chứng chỉ bón NPK.

\section{KIẾN NGH!}

Việc tiếp tục theo dõi và nghiên cứu thêm nhiều vụ thí nghiệm ngoài đồng là cần thiết để đánh giá được có hay không hiệu quả của chế phẩm vi khuẩn chứa 3 dòng vi khuẩn phân hủy $\mathrm{PBZ}$ trong nghiên cứu này lên sinh trưởng và năng suất cây lúa nếp ở thực tế đồng ruộng.

\section{LỜI CẢM ƠN}

Nghiên cứu này được tài trợ bởi Dự án Nâng cấp Trường Đại học Cần Thơ VN14-P6 bằng nguồn vốn vay ODA-A7 từ Chính phủ Nhật và sự hỗ trợ kinh phí từ Công ty Phân bón Đạm Cà Mau.

\section{TÀI LIỆU THAM KHẢO}

Dương Trúc Mai. (2019). Phân lập vi khuẩn tù lá thực vật có khả năng phân hủy hoạt chất kích thích ra hoa paclobutrazol (luận văn tốt nghiệp đại học). Trường Đại học Cần Thơ.

Đặng Phạm Thu Thảo. (2014). Phân lập các vi sinh vật bản địa có khả năng phân hủy thuốc kích thich ra hoa trái vu paclobutrazol trên nền đất vuờn trồng cây ăn trái ở một số tỉnh đồng bằng Sông Củu Long (đề tài nghiên cứu khoa học của sinh viên). Trường Đại học Cần Thơ.

Liu, H., Lin, T., Mao, J., Lu, H., Yang, D., Wang, J., \& Li, Q. (2015). Paclobutrazol Residue Determination in Potato and Soil Using Low Temperature Partition Extraction and Ultrahigh Performance Liquid Chromatography Tandem Mass Spectrometry. Journal of Analytical Methods in Chemical, 2015(4).

DOI: $10.1155 / 2015 / 404925$

MDAR. (2012). Paclobutrazol-Review Conducted by MDAR and MassDEP for Use in Sensitive Ares of Right-of-Way in Massachusetts. https://www.mass.gov/doc/paclobutrazol-reviewjan-2012pdf/

Nguyễn Ngọc Đệ. (2008). Giáo trình cây lúa. Thành phố Hồ Chi Minh: Nhà xuất bản Đại học Quốc gia Tp. Hồ Chí Minh.

Reddy, Y. T. N., \& Kurian, R. M. (2008).

Cumulative and Residual Effects of Paclobutrazol on Growth, Yield and Fruit Quality of 'Alphonso' Mango. Journal of Horticultural Sciences, 3(2), 119-122.

Silva, C. M. M. S., Vieira, R. F., \& Nicolella, G. (2003). Paclobutrazol effects on soil microorganisms. Applied Soil Ecology, 22 (1), 79-86.

Trần Văn Hâu, Đỗ Thị Út \&Trần Quốc Tuấn. (2001). Hiệu quả của Paclobutrazol trên sụ ra hoa trái vu của sầu riêng Sũa Hột Lép tại Trại thục nghiệm giống cây trồng Khoa Nông nghiệp, Trương ĐHCT. Hội nghị Tổng kêt chương trình IPM trên cây ăn trái ở ĐBSCL. Trường Đại học Cần Thơ.

Ueno, H., French, P. N., Kohli, A., \& Matsuyuki, H. (1987). Paclobutrazol: Control of Rice lodging in Japan, Proceding $11^{\text {th }}$ International Congress of Plant Protection. Manila.

Võ Công Thành. (2011). Phục tráng giống nếp CK92 có chất lượng tốt. Tạp chi khoa hoc Trường Đại hoc Cần Tho, 19b, 130-135.

Watson, G., \& Jacobs, K. (2012). Control of Apple Scab and Cytospora Canker with Paclobutrazol. Arboriculture and Urban Forestry, 38(3), 112-116.

Yoshida, S. (1981). Fundamentals of rice crop science. IRRI, Los Banos, Laguna, Philippines. 